\title{
Removal of Hydrocarbons from Contaminated Soils Using Bioremediation by Aerobic Co-composting Methods at Ship Dismantle Locations
}

\author{
Rizki Mona Syawlia ${ }^{1 *}$, Harmin Sulistiyaning Titah ${ }^{1}$ \\ 1 Department of Environmental Engineering, Faculty of Civil, Planning and Geo Engineering, Institut \\ Teknologi Sepuluh Nopember, Keputih, Sukolilo, 60111, Surabaya, Indonesia \\ * Corresponding author's e-mail: rizkimona95@gmail.com
}

\begin{abstract}
This research focused on hydrocarbon removal from contaminated soil, using co-composting methods on a laboratory scale. The soil samples were taken from ship demolition sites in Tanjung Jati, Bangkalan Regency, Madura Island. Therefore, this study aimed to investigate the efficiency of bioremediation process using the co-composting method for hydrocarbon removal. The co-composting was treated under aerobic conditions, and manual stirring for aeration was performed every 2 days. Moreover, the values of hydrocarbon and total bacterial population levels were measured on day 0,30 , and 60 . The results of the study at location 1 showed that for 60 days, the cocomposting of contaminated soil in the control reactor was $33.36 \%$, kitchen waste $(34.99 \%)$, local cattle rumen waste $(59.41 \%)$, and soil mixed kitchen and cattle rumen waste $(61.01 \%)$. Meanwhile, at location 2 , they were $28.50 \%, 64.18 \%, 42.67 \%$, and $67.03 \%$ respectively. The largest total bacterial population was in the nutrient agar media with stratification of up to $10^{-8}$.
\end{abstract}

Keywords: aerobics, co-composting, hydrocarbons, kitchen waste, slaughterhouse waste.

\section{INTRODUCTION}

Ship demolition causes changes in environmental conditions due to the influx of pollutants that are mostly hydrocarbons. The spills of these chemical compounds, such as diesel, bunkers, oil, and grease occur when ships are unloaded in parts. Their high concentrations in soil can damage the physical and chemical properties. In fact, the oil types increase the bulk density of soil, decrease its capacity to absorb water; increase its organic matter, carbon, and nitrogen content. Furthermore, it reduces the content of phosphorus, magnesium, calcium, sodium, and potassium. In addition, it reduces the penetration of plant roots into the soil (Kayode et al., 2009; Nwite and Alu, 2015).

Hydrocarbons are one of the most common contaminants that require remediation, and they are indications of water pollution (Kirk et al., 2004). These compounds in soil are difficult to decipher, and are toxic to the growth of plants and other organisms. According to Handrianto et al. (2012), the components of hydrocarbons are organic compounds. Therefore, the soils that are contaminated are not suitable for plant growth, and are difficult to degrade by micro-organisms (Chijioke-Osuji et al., 2014). Currently, there are different types of technologies to improve the affected areas. One of them is the remediation of contaminated soil and groundwater using the bioremediation techniques (Wang et al., 2011). This is widely used because it is inexpensive and environmentally friendly compared to others (Zhang et al., 2012).

Bioremediation can be done in-situ and exsitu. The ex-situ technique involves the physical transfer of the contaminated material to a location for further treatment. This means that the waste is taken from one place and then treated in another, after which it is returned to the initial location and then specially treated using microbes. This process is faster and easier to control, and can remediate diverse types of contaminants compared 
to ex-situ (Vidali, 2001). One of the ex-situ techniques for removing hydrocarbons is the co-composting method (Wang et al., 2011). This is done by mixing the soil with biodegradable organic waste to add nutrients and enhance the activities of micro-organisms that remove the pollutants (Mizwar and Trihadiningrum, 2016). Some of the advantages of this method are its low operational costs, simple design, and high processing efficiency (Namkoong et al., 2002). Furthermore, it improves the soil properties and re-use of biodegradable organic waste (Sayara et al., 2010).

Aerobic conditions and appropriate micro-organisms are necessary for an optimal rate of bioremediation. In soils, the oxygen content depends on microbial activity, texture, water, and depth. Low oxygen has been shown to limit the bioremediation of soils contaminated with petroleum hydrocarbons (von Wedel et al., 1988). Moreover, in a laboratory experiment, mineralization from soil was severely limited when the oxygen content was below 10\% (Freijer, 1986). Tillage means the mechanical manipulation of soil to improve its conditions (Hillel, 1980). It also alters the physical and chemical properties by stimulating the microbial activity (Melope et al., 1987).

This process helps to reorganize carbon, nitrogen, and water, as well as reduces spatial distribution within the soil (Rhykerd et al., 1999). Bulking agents are the materials that lower the bulk density of soil, increase porosity and oxygen diffusion, and also help to form water-stable aggregates. These activities increase aeration and microbial activity (Hillel, 1980). Additional materials such as bacterial consortium, inorganic supplements, and bulking agents are used to enhance remediation.

Therefore, this study aimed to determine the ability of aerobic co-composting methods using the biodegradable organic waste from kitchens and slaughterhouses in hydrocarbon removal.

\section{MATERIALS AND METHODS}

\section{Sampling for Contaminated Soils}

The soil used in this study was obtained from a ship demolition site in Tanjung Jati, Bangkalan, Madura. Retrieval of contaminated land was divided into two locations. The difference between the two sites was when the ship was unloaded. Location 2 had a longer operating time than 1, and the distance between them was $193.16 \mathrm{~m}$. The soil from the two locations was sieved with mesh size of $1 \mathrm{~cm}$ to separate rocks, twigs, rubber, and broken iron. It was then weighed at $2 \mathrm{~kg}$, placed in a labelled zip lock plastic and stored at room temperature. Afterwards, it was then placed into a reactor, which contained as much as $2 \mathrm{~kg}$ each.

\section{Characteristics of Biodegradable Organic Waste}

The biodegradable organic waste originated from kitchens and slaughterhouses. Each type of waste was chopped in the compost house using a chopper. After preparing all the samples, contaminated soil, sawdust, and organic waste were weighed and placed in each reactor. After the soil was polluted and the waste was mixed, each reactor was stirred $10-15$ times to make it homogeneous.

\section{Reactor Preparation}

During the study, 16 rectangular shaped reactors were made of thick plastic with a size of $44 \mathrm{~cm} \times 30 \mathrm{~cm} \times 11 \mathrm{~cm}$, each. They contain the contaminated soils from two different locations, a consortium of Bacillus subtilis bacteria, Acinetobacter iwoffii, sawdust, and organic waste from local cattle rumen and kitchens. The research was conducted by duplo with different reactor name tags.

\section{Composting Time}

The co-composting time was 60 days. Atagana (2008) stated that Total Petroleum Hydrocarbon (TPH) was degraded to $67.8 \%$ using a mixture of sludge from sewage and garden waste at a ratio of 50:50\% for 2 months. Hapsari and Trihadiningrum (2014) suggested that co-composting of oily sludge, household waste, and livestock manure with a composition of $55: 45 \%$ was able to reduce oil pollutants to $72 \%$ in 60 days.

\section{Addition of Sawdust as a Bulking Agent}

Sawdust was added as a bulking agent. This process increased the soil porosity, which enhances the oxygen availability to the degrading microorganisms (Fingas, 2011). Sawdust with a particle size of $0.85-1.70 \mathrm{~mm}$ can absorb 6.4 grams of crude oil in 24 hours (Annunciado et al., 2005). 


\section{Addition of Bacterial Consortium}

The Bacillus subtilis bacteria were isolated by Pranowo and Titah (2016), while Acinetobacter lwoffii by Nadhirawaty (2019) and Imron (2018). Both of these strains of bacteria were isolated directly from the contaminated soil in the same location.

\section{Laboratory Analysis}

\section{Analysis of Total Petroleum Hydrocarbon (TPH)}

The test samples of 10 grams per reactor, 10 grams of anhydrous $\mathrm{Na}_{2} \mathrm{SO}_{4}$, and $35 \mathrm{ml}$ of $\mathrm{n}$-hexane were placed in a $100 \mathrm{ml}$ Duran bottle. The sample was then extracted using a 100-watt ultrasonic water bath (Krisbow, Indonesia) at a temperature of $50^{\circ} \mathrm{C}$ for 60 mins. The extraction results were filtered using a glass wool and placed in a beaker, followed by adding $25 \mathrm{ml}$ of $\mathrm{n}$-hexane. The results were then left in the fume hood for 3-4 days.

The weight difference of the extracted liquid before and after evaporation was recorded as a total value of petroleum hydrocarbons (Formula 3.1) according to US EPA 3540. After weighing and gravimetrically calculating the TPH values, $10 \mathrm{ml} \mathrm{n}$-hexane was added to the sample results and placed in a glass sample bottle and sealed. The gas chromatography tool used was GC-2010 Shimadzu. This separation technique is based on the difference in equilibrium distribution of sample components between a mobile and stationary phase. The compounds which are separated with gas chromatography are volatile and stable at operating temperatures. This means they should not break down into other compounds at that temperature.

There were two types of GC analysis, which are qualitative and quantitative. The qualitative method was used to compare the retention times and co-chromatography. Therefore, before measuring the samples, standard measurements were taken. The standard used was $0.1 \%$ diesel which is most likely contained in the samples. After preparing the standard solution, they were then injected into the gas chromatography instrument.

\section{Analysis of Total Bacteria Population}

Four types of Agar media for bacterial growth were used, which are Nutrient, Bacillus Differentiation, Herella, and HicromeTM Bacillus. The number of bacteria growths in each media was different; therefore, the agar dilution differed depending on the colonies. 1 gram of test sample was placed in a test tube, followed by adding $9 \mathrm{ml}$ of sterile $\mathrm{NaCl}$. For the pour plate analytic method, $1 \mathrm{ml}$ of the sample was transferred with a sterile pipette into a $9 \mathrm{ml} \mathrm{NaCl}$ solution to obtain 10-2, $10-3$, and $10-4$ dilutions. This was followed by inoculating $1 \mathrm{ml}$ suspension (culture media) of each dilution in an empty petri dish. Before being placed into a petri dish, the test sample was homogenized and the liquid agar media was poured and mixed with the sample, then incubated at $37^{\circ} \mathrm{C}$ for a day. The results of the growth were then calculated using a Colony Counter. After one day, the bacteria were counted by the number of colonies.

\section{RESULTS AND DISCUSSION}

\section{Soil Characteristics Test from Sampling Locations}

Two ship demolition sites were the main materials in this study, which are locations 1 and 2 in Tanjung Jati Village, Bangkalan Regency, Madura Island. This village is one of the famous places for ship demolition in Indonesia. Shipbuilders take old and inoperable vessels and process them into brand new products. A ship is made of steel; therefore, the main target of dismantling these old vessels is to obtain steel as raw material for constructing new ships or other products.

During this process, hydrocarbon compounds can spill from tanks, pipes, engines, ballast water, fuel, oil waste and grease, especially during the vessel cleaning stage (UNEP, 2003). In addition, the ship dismantling activities are closely related to environmental pollution by heavy metals, such as iron $(\mathrm{Fe})$, lead $(\mathrm{Pb})$, mercury $(\mathrm{Hg})$, cadmium $(\mathrm{Cd})$, aluminum ( $\mathrm{Al})$, and zinc $(\mathrm{Zn})$. Fe is a contaminant that is generally found in high concentrations at ship unloading sites (Rahman, 2017).

\section{Monitoring Parameters}

The monitoring parameters measured involved temperature, $\mathrm{pH}$, and moisture content. These are important elements because success in the co-composting process is to fulfill all three parameters. During 60 days of co-composting, the temperatures at locations 1 and 2 tended to 
be stable with a temperature range of $35.5-36^{\circ} \mathrm{C}$. According to Bernal et al. (2009), the compost temperature, which tends to be the same, is due to the low thickness of compost heap so that the temperature does not reach the thermophilic stage $\left(40-65^{\circ} \mathrm{C}\right)$ which is optimal for aerobic composting, because the stack height is one of the factors that determine the temperature composting. Piles of material that are too low will result in rapid heat loss due to insufficient material to hold the heat released, so that microorganisms cannot develop optimally. Conversely, if the pile is too high, the material density will occur due to the weight of the material so that the temperature becomes very high and there is no air in the pile (Fitri et al., 2012).

The $\mathrm{pH}$ range $6-8$ is the optimal $\mathrm{pH}$ value for microbial activity during co-composting (Miller, 1992). During 60 days of co-composting, the $\mathrm{pH}$ in the reactor ranges between 6.6-7.0. The $\mathrm{pH}$ value is classified as neutral and is in the optimum $\mathrm{pH}$ range for composting. In the first 10 days, the $\mathrm{pH}$ value tends to be stable and not increase. Increasing $\mathrm{pH}$ value indicates an increase in the activity of microorganisms in degrading organic matter and shows that the overhaul of organic compounds of carbon compounds into organic acids is no longer a dominant process. The formation of ammonium compounds can increase the $\mathrm{pH}$ value (Ismayana et al., 2012).

\section{Analysis of Organic and Inorganic Parameters in the Form of (Total Petroleum Hydrocarbon) and Fe Analysis}

The co-composting of contaminated soils and biodegradable waste for 60 days was aimed at determine its effect on hydrocarbons removal. This analysis was performed using gravimetry and GC. The results of the gravimetric analysis during co-composting can be seen in Figures 1 and 2.

At Location 1, day 0, the TPH levels were $23,216.9 \mathrm{mg} / \mathrm{kg}$ for the control reactor, the contaminated soil and kitchen waste was $24,355.2 \mathrm{mg} / \mathrm{kg}$, the soil and rumen were $32,959.4 \mathrm{mg} / \mathrm{kg}$, and the mixture of kitchen and rumen waste was $31,598.6 \mathrm{mg} / \mathrm{kg}$. In turn, at location 2 , the TPH levels on day 0 , both in the control and test reactor were $21,546.4 \mathrm{mg} / \mathrm{kg}, 38,277.8 \mathrm{mg} / \mathrm{kg}$, $24,334.9 \mathrm{mg} / \mathrm{kg}$, and $34,875.8 \mathrm{mg} / \mathrm{kg}$ respectively.

At Location 1 and 2, the average value of the control reactor has a hydrocarbon allowance of $31.51 \%$ and $26.80 \%$, respectively. The removal in this reactor does not have a high percentage value,

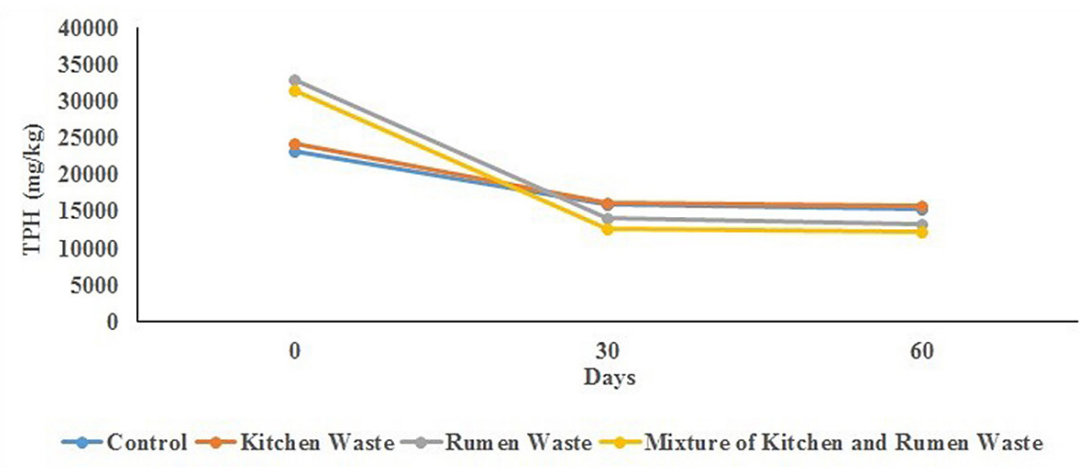

Figure 1. TPH Content for 60 Days of Co-Composting Process in Soil Sample at Location 1

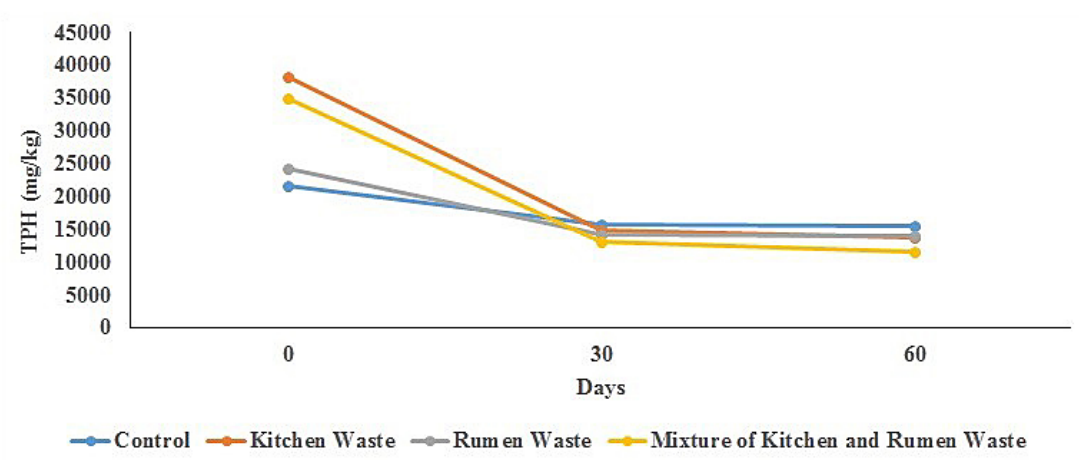

Figure 2. TPH Content for 60 Days of Co-Composting Process in Soil Sample at Location 2 
because the co-composting process was only aided by micro-organisms activity. The soil and kitchen waste percentage allowance were $33.80 \%$ and $60.90 \%$, the soil and rumen were $57.10 \%$ and $41.40 \%$. Lastly, the mixture of kitchen and rumen waste were $59.90 \%$ and $62.60 \%$, respectively.

At the end of co-composting on day 60 , the percentage of allowance for hydrocarbons was higher. The reduction during the 60 days occurs due to less organic compounds present in the compost material. This causes the bacteria to lack nutrients for metabolism, which in turn reduces the process of organic and hydrocarbons decomposition.

The percentage at location 1 and 2 on day 60 is the average value of the control reactor having an allowance of $33.36 \%$ and $28.50 \%$. Contaminant removal in this reactor does not have a high percentage value because the co-composting process was only aided by micro-organisms activity. In soil reactors and kitchen waste, the percentage allowance was $34.99 \%$ and $64.18 \%$, soil and rumen waste were $59.41 \%$ and $42.67 \%$, and soil mixed kitchen and rumen waste were $61.01 \%$ and $67.03 \%$, respectively. The decrease in the hydrocarbon levels occurs due to addition of organic waste to the compost, which accelerates the activity and development of bacterial population (Atagana, 2008).

The best results were seen in the reactors with the mixture of kitchen waste and local cattle rumen with $67.03 \%$ allowance. This showed that the higher the organic waste composition, the greater the amount of removed hydrocarbons. Organic waste, as an additional nutrient (starter) helps to accelerate the activity of micro-organisms in decomposing and degrading organic materials. Van Gestel et al. (2003) claimed that hydrocarbons could be optimally removed (86\%) at a faster rate (12 weeks) on co-composting with a mixture of organic waste (vegetable, fruit, and dry leaves). The research further explained that higher concentration of organic waste could accelerate decomposition.

Gas chromatography (GC) is a common type of chromatography used in analytical chemistry for separating and analyzing compounds that can be vaporized without decomposition. The typical uses of GC include testing the purity of a particular substance, or separating the different components of a mixture (the relative amounts of such components can also be determined). In some situations, GC may help in identifying a compound.
In preparative chromatography, GC can be used to prepare pure compounds from a mixture. In gas chromatography, the mobile phase (or "moving phase") is a carrier gas, usually an inert gas such as helium or an unreactive gas such as nitrogen. The gaseous compounds being analyzed interact with the walls of the column, which is coated with a stationary phase. This causes each compound to elute at a different time, known as the retention time of the compound. The comparison of retention times is what gives GC its analytical usefulness (Pavia, 2006).

In this study, the standard solution used was $0.1 \%$ diesel. The sample used is hydrocarbons. In order to identify the $0.1 \%$ solar content obtained by comparing the standard retention time with the sample retention time. Retention times are typical for each compound under the same conditions or parameters. If the retention time in the sample is the same as the retention time at the standard, then the sample contains the same components as the standard. The retention time tolerance is 0.01 . If the retention value of the standard solution and the sample are the same or close together, it can be said that the sample of polluted soil used contains diesel.

Figure 3 and 4 show the visualization of results on gas chromatography in the soil samples with kitchen waste, it can be seen that there is a difference in retention time between days 0 and 60. This shows the occurrence of carbon chain terminations so that the retention time is shorter.

The measured metal parameter was iron $(\mathrm{Fe})$, which is silvery white in appearance (Yudo, 2006). This element is an important component of cytochrome pigments in cellular respiration, and also an enzyme cofactor in micro-organisms. However, its high concentration can pollute the environment, and cause harm to organisms (Prescott, 2008). Fe is an essential metal, in which its availability is needed by living organisms at certain amount, but its excess can cause toxic effects. Therefore, its high content has an impact on human health (Parulian, 2009).

In general, iron in ground water can be dissolved as $\mathrm{Fe}^{2+}$ or $\mathrm{Fe}^{3+}$. The high $\mathrm{Fe}\left(\mathrm{Fe}^{2+}, \mathrm{Fe}^{3+}\right)$ content is related to the soil structure. The iron in water is in the divalent $\left(\mathrm{Fe}^{2+}\right)$ and trivalent form $\left(\mathrm{Fe}^{3+}\right)$, and sometimes, it binds with other elements in the form of $\mathrm{Fe}_{2} \mathrm{O}_{3}, \mathrm{Fe}(\mathrm{OH})_{2}, \mathrm{Fe}(\mathrm{OH})_{3}$, or $\mathrm{FeSO}_{4}$. It was also stated that the iron in water comes from within the soil and other sources, including iron pipes and industrial waste deposits (Ronquillo, 2009). 


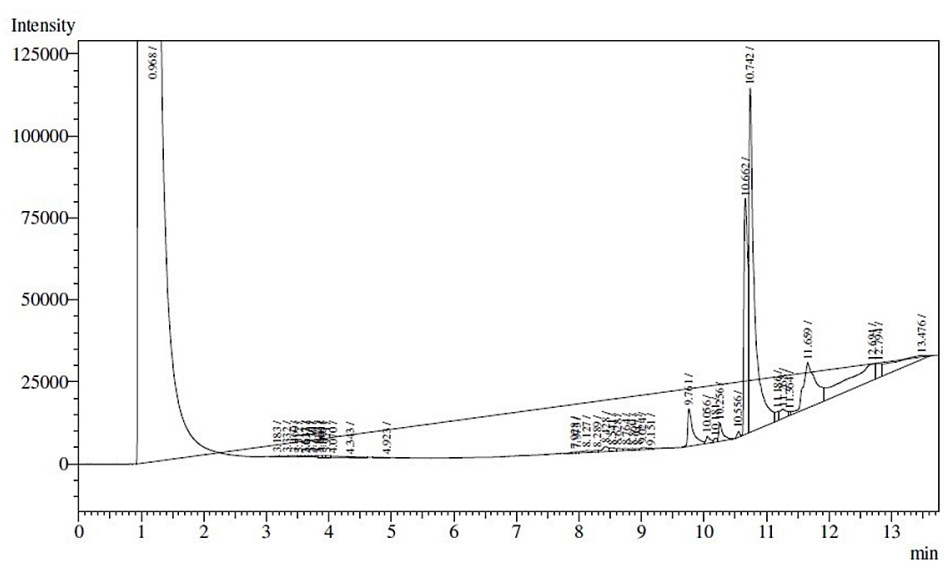

Figure 3. Visualization of Chain C Breaking in Kitchen Waste Samples on Day 0

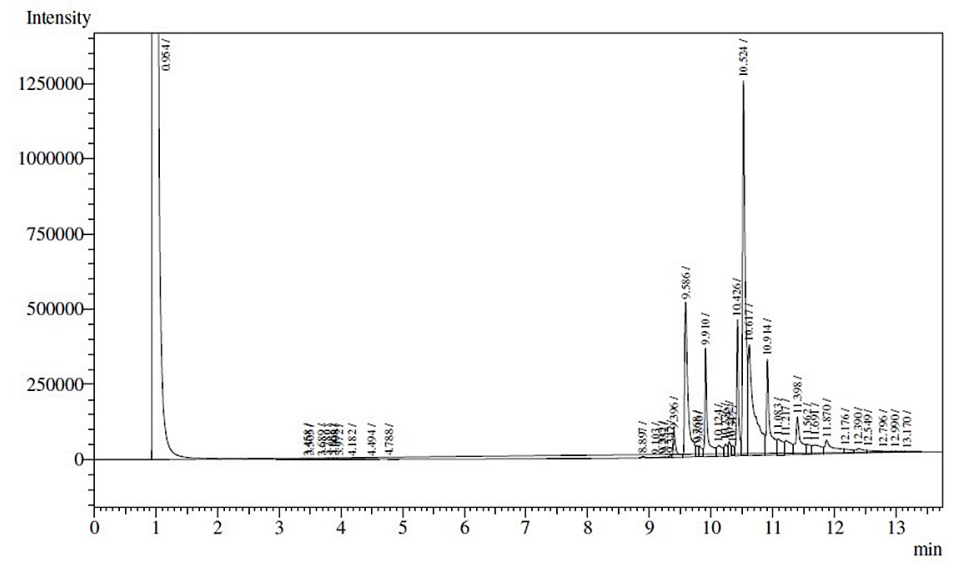

Figure 4. Visualization of Chain C Termination in Kitchen Waste Samples on Day 60

The heavy metal parameters were analyzed using Inductively Coupled Plasma (ICP), which is an analytical technique for detecting trace metals in environmental samples. This method is highly appropriate for analyzing low concentration metals that make up complex mixtures. The sensitivity and detection limits are parameters that are often used in ICP, and both can vary with changes in temperature and bandwidth of the spectra. In this analysis, the measured iron content was the level of dissolved Fe. The results of the metal parameter Fe analysis during co-composting can be seen in Figures 5 and 6.

At Location 1 day 0 , the Fe levels in the control reactor showed a value of $1104.2 \mathrm{mg} / \mathrm{kg}$ which was the lowest. Meanwhile, the highest Fe content was in the soil and rumen waste reactor which was $1386.25 \mathrm{mg} / \mathrm{kg}$. On day 30 , the concentration of heavy metals decreased in all reactors. In the control, it was reduced to $376.9 \mathrm{mg} / \mathrm{kg}$ (65.86\% allowance), and to $648 \mathrm{mg} / \mathrm{kg}(50.42 \%$ allowance) in soil and kitchen waste. Furthermore, it was reduced to $500.9 \mathrm{mg} / \mathrm{kg}(63.86 \%$ allowance) in the soil and rumen waste reactor, and to $710.40 \mathrm{mg} / \mathrm{kg}$ (allowance of 40.65 ) in soil mixture of kitchen and rumen waste.

On the 60th day, there was a significant decrease with a higher percentage of allowance. In the control reactor, there was Fe reduction to $94.25 \mathrm{mg} / \mathrm{kg}$ (allowance $91.46 \%$ ), contaminated soil and kitchen waste Fe reduced to $80.9 \mathrm{mg} / \mathrm{kg}$ (allowance 93.81\%). Moreover, in the soil and rumen waste reactor, it decreased to $144.5 \mathrm{mg} / \mathrm{kg}$ (89.57\% allowance), and in the mixture of kitchen and rumen waste reactor, it reduced to $156 \mathrm{mg} / \mathrm{kg}$ (86.96\% allowance).

The reduction and elimination of the heavy metal content was influenced by the addition of a consortium and indigenous bacteria in organic waste. According to Baby et al. (2014), all Bacillus genera can grow in $\mathrm{Fe}$-containing media, because the iron is needed for cell metabolism. They also stated that all micro-organisms, including Bacillus, need $\mathrm{Fe}$ for metabolic activity, and also as a major structural component in several enzymes. However, Baby et al. (2013) stated that 


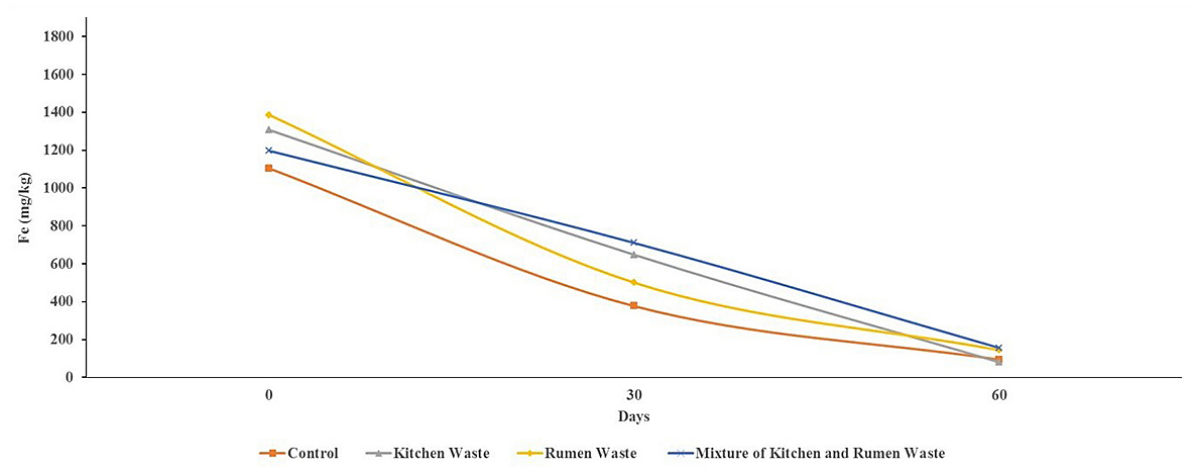

Figure 5. Fe Heavy Metal Content for 60 Days of Co-Composting Process in Soil Sample at Location 1

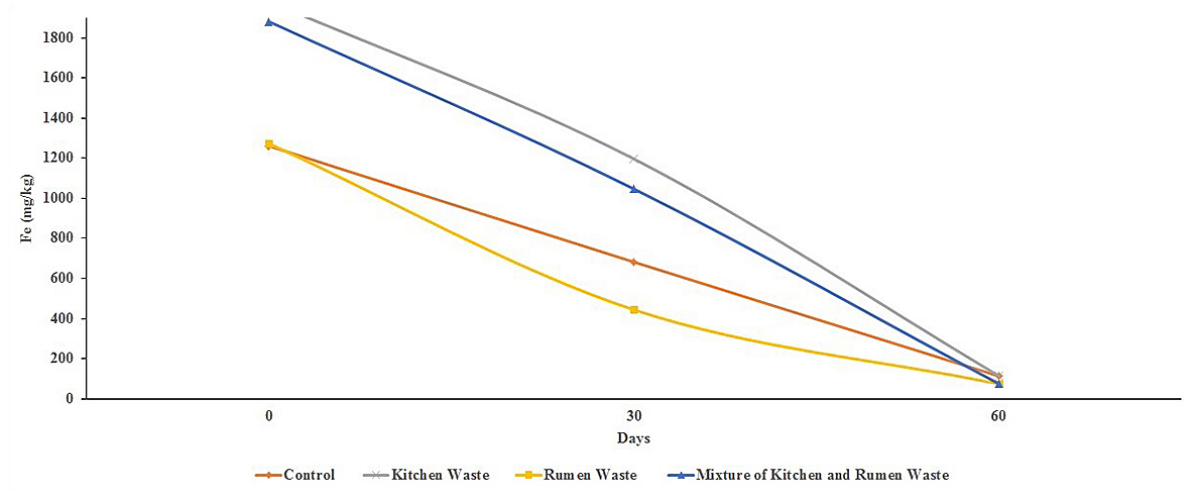

Figure 6. Fe Heavy Metal Content for 60 Days of Co-Composting Process in Soil Sample at Location 2

some Bacillus species are resistant to Fe up to $6000 \mathrm{mg} / \mathrm{kg}$.

According to Chojnacka (2010), the bacteria that are isolated from heavy metal polluted environments have high resistance. Basically, the populations of micro-organisms that are resistant to metals have changes in solubility, accumulation, and in-situ immobilization (Baby et al., 2013).

The analysis of the hydrocarbon content parameters in each reactor was conducted with the ANOVA Two-way statistical test. This was done to determine the effect of each independent variable (type of organic waste and the composition of soil contaminated with crude oil and organic waste) on the dependent (removal rate of hydrocarbon levels). The ANOVA test in this study uses Minitab 16 software, with the aim to determine the significance of each variable. The results showed the variable that most influenced the efficiency of decreasing hydrocarbon levels in crude oil contaminated soil.

The confidence level of this statistical test was $95 \%$, and the accepted error rate in a laboratory was 5\% (Kuswadi and Mutiara, 2004). Significant influence in statistical tests was indicated by a $\mathrm{P}$-value smaller than $0.05(\mathrm{P}<0.05)$. This value showed the variable significantly influenced the level of allowance for the hydrocarbon content. Conversely, when the value is $>0.05$, then the variable does not significantly influence the level of allowance in crude oil polluted soils. On the basis of the ANOVA results on days 0,30 , and 60 , the location does not affect the hydrocarbon removal. Meanwhile, the composition variation affects it.

\section{Analysis of Total Changes in Bacterial Populations}

Population analysis was conducted to determine the number of bacteria in each treatment. Four types of agar media were used, which are Nutrient (NA), Bacillus Differentiation, HicromeTM Bacillus, and Herella. The use of selective media functions as a medium that allows a particular type of microbe to grow while others are inhibited.

The selective media involve the addition of certain substances to inhibit the growth of undesirable microbes. The Agar Nutrient (NA) is a general media that allows the growth of several types of bacteria. Bacillus Differentiation Agar 
was used to determine the population of Bacillus subtilis bacteria in each reactor, while Herella was used to determine the population level of Acinetobacter iwoffii.

On the basis of several studies, it is known that the local cattle rumen contains Bacillus pumilus. Therefore, selective media was used for HicromeTM Bacillus in order to determine their population in the co-composting process. This was also done to ascertain the type of bacteria with the highest potential of removing hydrocarbons. The results of calculating the number in Nutrient Agar (NA) media can be seen in Figures 5 and 6 .

Some bacteria have developed several efficient systems for metal detoxification. The mechanism can be classified into 5 categories, which are: (1) intracellular absorption; (2) exporting; (3) reduction; (4) extracellular absorption; and (5) extracellular detoxification. Nearly all bacterial resistance mechanisms encode the genes that are found in plasmids and transposons. This allows gene transfer or spontaneous mutation that enhances their metal resistance.
Resistant bacteria are expected to remediate metal contamination in the environment. This can be achieved through the mechanism of biosorption and bioaccumulation. The biosorption is a passive process that prevents metal poisoning. Meanwhile, bioaccumulation is active where heavy metals poison bacterial cells (Chojnacka, 2010). The mechanism of tolerance by complexation includes the production of extracellular polysaccharides which have anions, and functions as efficient as bio accumulators. It also includes precipitation, extracellular crystallization, and the production of organic metabolites that have chelating properties and form complexes with metals (Saraswati, 2007). The results of total changes in bacterial populations analysis during co-composting can be seen in Figures 7 and 8.

In Nutrient Agar (NA) media, $10^{-8}$ levels of dilution were used. The lowest bacterial population was at location 1 reactor control on day 0 . Meanwhile, the highest number was found in the contaminated soil mixture of kitchen and rumen waste in both locations.

In the Bacillus Differentiation, $10^{-7}$ strata dilutions were used, while $10^{-5}$ stages were used

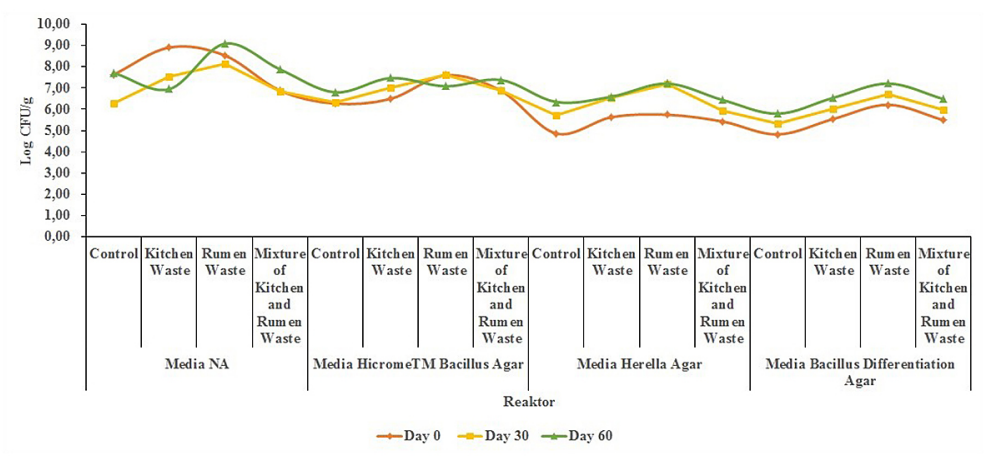

Figure 7. Total Changes in Bacteria Population during 60 Days of Co-Composting Process in Soil Samples at Location 1

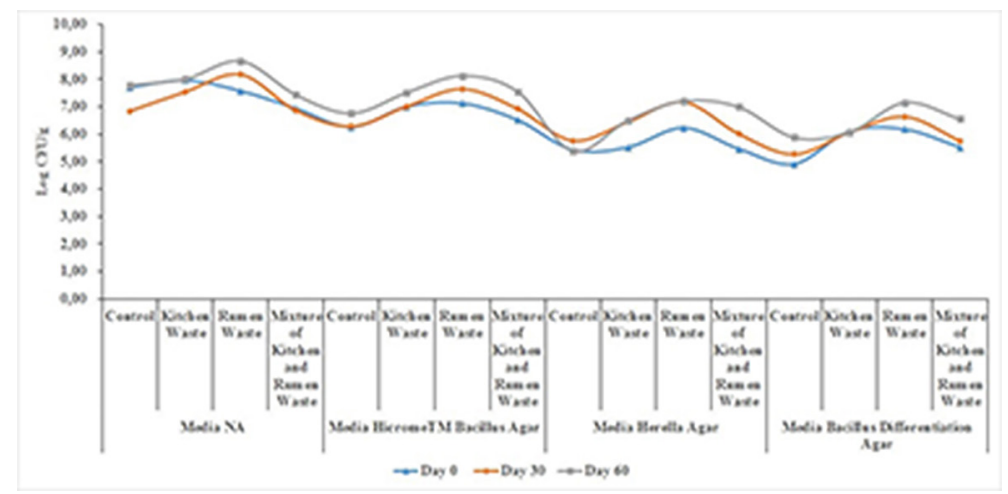

Figure 8. Total Changes in Bacteria Populations during 60 Days of Co-Composting Process in Soil Samples at Location 2 
in Herella. The population of both media for all reactors is in the control for location 1 and 2. In Herella, the highest number of bacterial populations was in the control reactor at location 1. In turn, in Bacillus Differentiation media, the highest was at location 2. Meanwhile, on day 60, the highest population was in the contaminated soil and local cattle rumen waste reactor.

\section{CONCLUSIONS}

It was concluded that the type of organic waste source with the best efficiency for hydrocarbon removal was soil with a mixture of cattle rumen waste. Meanwhile, the best efficiency bacterial consortium was in nutrient agar (NA) media with a dilution rate of up to $10^{-8}$. In conclusion, it showed the highest of bacterial population.

\section{Acknowledgement}

The author would like to thank KemenristekDIKTI (Ministry of Research, Technology and Higher Education, Republic of Indonesia) through the scheme of Penelitian Terapan Unggulan Perguruan Tinggi - third year research, PTUPT 2019 for funding this research. No of contract: 5/E1/ KP.PTNBH/2019 and No. 998/PKS/ITS/2019.

\section{REFERENCES}

1. Annunciado, T.R., Sydenstricker, H.D., \& Amico, S.C. 2005. Experimental Investigation of Various Vegetable Fibers as Sorbent Materials for Oil Spills. Marine Pollution Bulletin, 50(11), 1340-1346.

2. Atagana, H.I. 2008. Compost Bioremediation of Hydrocarbon-Contaminated Soil Inoculated with Organic Manure. African Journal of Biotechnology, 7(10), 1516-1525.

3. Baby, V., Rajakumar, S., \& Ayyasamy, P.M. 2013. Reduction of Ferric Iron in Synthetic Medium Amended with Acetate as A Sole Carbon Source. International Journal of Current Microbiology and Applied Sciences, 2(12), 501-513.

4. Baby, V., Rajakumar, S., \& Ayyasamy, P.M. 2014. Prevalence and Screening of Potential Fe (III) and Mn (VI) Resistant Microorganisms in Industrial Soil. International Journal of Innovative Research in Science, Engineering and Technology, 3, 7.

5. Bernal, M.P., Alburquerque, J.A., \& Moral, R. 2009. Composting of Animal Manures and Chemical Criteria for Compost Maturity Assessment A Review.
Bioresource Technology, 100, 5444-5453.

6. Chijioke-Osuji, C.C., Ibegbulam-Njoku, P.N., \& Belford, E.J.D. 2014. Biodegradation of Crude Oil Polluted Soil by Co-Composting with Agricultural Wastes and Inorganic Fertilizer. Journal of Natural Sciences Research, 4(6), 28-39.

7. Chojnacka, K. 2010. Biosorption dan Bioaccumulation, the prospect of partial application. Environment International. 36: 299-307

8. Fingas, M. 2011. Oil Spill Science and Technology: Prevention, Response, and Clean Up. In: M. Fingas, Ed. (1st ed.). United State of America: Elsevier Inc.

9. Fitri, S.N.A., Jayanti, C.S., \& Budianta, D. 2012. Dinamika Mikrobia dari berbagai Bahan Organik yang Didekomposisi menjadi Kompos. Agria, 7 (2), 208-217.

10. Freijer J.I. 1986. Mineralization of Hydrocarbons in Soil Under Decreasing Oxygen Availability. J Environ Qual ; 25:296 \pm 304

11. Handrianto, P., Rahayu, S.Y., \& Yuliani. 2012. Teknologi Bioremediasi dalam Mengatasi Tanah Tercemar Hidrokarbon. Prosiding Seminar Nasional Kimia Unesa 2012, Surabaya: FMIPA Universitas Negeri Surabaya, 25 Februari 2012, 22-30.

12. Hapsari, P.P. and Trihadiningrum, Y. 2014. Pengolahan Lumpur Berminyak dengan Metode Cocomposting. Surabaya: Jurusan Teknik Lingkungan, FTSP-ITS.

13. Hillel D. 1980. Soil Structure and Aggregation. In: Introduction to Soil Physics, London: Academic Press. pp. 40-52, 200-204.

14. Imron, M.F. 2017. Optimasi Proses Biodegradasi Solar oleh Isolat Bakteri dengan Menggunakan Response Surface Methodology (RSM) Desain Box Behnken. Institut Teknologi Sepuluh Nopember, Surabaya.

15. Ismayana, A., Indrasti, N.S., Suprihatin, A., Maddu, A., dan Fredy. 2012. Faktor Rasio C/N Awal dan Laju Aerasi pada Proses Co-Composting Bagasse dan Blotong. Jurnal Teknologi Industri Pertanian, 22(3), 173-179.

16. Kayode, J., Oyedeji, A.A., \& Olowoyo, O. 2009. Evaluation of the Effects of Pollution with Spent Lubricating Oil on the Physical and Chemical Properties of Soil. The Pacific Journal of Science and Technology, 10(1), 387-391.

17. Kirk, J.L., Beaudette, L.A., Hart, M., Moutoglis, P., Klironomos, J.N., Lee, H., \& Trevors, J.T. 2004. Methods of Studying Soil Microbial Diversity. Journal of Microbiological Methods, 58, 169-188.

18. Kuswadi and Mutiara, E. 2004. Statistik Berbasis Komputer untuk Orang-Orang Statistik. Jakarta: PT. Elex Media Komputindo.

19. Melope MB. 1987. Griwe IC, Pege ER. Contributions by Fungi and Bacteria to Aggregate Stability 
of Cultivated Soils. J Soil Sci; 38, 71-77.

20. Miller, F.C. 1992. Composting as A Process Based on The Control of Ecologically Selective Factors. Metting F.B. Jr. (Ed), Soil Microbial Ecology, Applications in Agricultural and Environmental Management, New York: Marcel Dekker, Inc, Page. 515-544.

21. Mizwar, A., and Trihadiningrum, Y. 2014. Potensi Bioremediasi Tanah Terkontaminasi Polycyclic Aromatic Hydrocarbons dari Batubara dengan Composting. Seminar Nasional Waste Management II.

22. Namkoong, W., Hwang, E., Park, J., and Choi, J. 2002. Bioremediation of Diesel Contaminated Soil with Composting. Environmental Pollution, 119, 23-31.

23. Nwite, J.N., \& Alu, M. 2015. Effect of Different Levels of Spent Engine Oil on Soil Porperties, Grain Yield of Maize and Its Heavy Metal Uptake in Abakaliki, Southeastern Nigeria. Journal of Soil Science and Environmental Management, 5(4), 44-51.

24. Nadhirawaty, R. 2019. Bioremediasi Tanah Tercemar Hidrokarbon di Lokasi Pembongkaran Kapal Kabupaten Bangkalan Madura. Surabaya: Jurusan Teknik Lingkungan, FTSLK-ITS.

25. Parulian, A. 2009. Monitoring dan Analisis Kadar Aluminium (Al) dan Besi (Fe) Pada Pengolahan Air Minum PDAM Tirtanadi Sunggal. Medan : Pascasarjana Universitas Sumatera Utara (USU).

26. Pavia, L., Gary M. Lampman, George S. Kritz, \& Randall G. Engel. 2006. Introduction to Organic Laboratory Techniques (4th Ed.). Thomson Brooks/ Cole. pp. 797-817.

27. Pranowo, P.P., \& Titah, H.S. 2016. Isolation and Screening of Diesel-Degrading Bacteria from the Diesel Contaminated Seawater at Kenjeran Beach, Surabaya. Environment Asia, 9(2), 165-169.

28. Prescott GW. 2008. How to Know the Freshwater Algae W. Lowa: Mc Brown Co.Publ.

29. Rahman, S. 2017. Aspects and impacts of ship recycling in Bangladesh. Procedia Engineering, 194, 268-275.

30. Rhykerd RL, Crews B, McInnes KJ, \& Weaver RW. 1987. Impact of Bulking Agents, Forced Aeration and Tillage on Remediation of Oil-Contaminated Soil. Biores Technol, 67, 279-85.

31. Rosado, JL., Lopez, P., Kordas, K., Vargas, GC., Ronquillo, D., Alatorre, J., \& Stoltzfus, RJ. 2006. Iron and / or Zink Supplementation Did Not Reduce Lead Concntration in Children in Randomized, Placebo - Controlled Trial. J. Nutr. 136 - 2378 - 2383.

32. Saraswati and Anwar E.K. 2006. Kompos. Balit Tanah. Departemen Pertanian.

33. Sayara, T., Borras, E., Caminal, G., Sarra, M., \& Sanchez, A. 2011. Bioremediation of PAHs Contaminated Soil Through Composting: Influence of Bioaugmentation and Biostimulation on Contaminant Biodegradation. International Biodeterioration and Biodegradation, 65, 859-865.

34. UNEP, B.C. of. 2003. Technical Guidelines for the Environmentally Sound 73 Management of the Full dan Partial Dismantling of Ships. Switzerland: United Nations Environment Programme (UNEP).

35. Van Gestel, K., Mergaert, J., Swings, J., Coosemans, J., \& Ryckeboer J. 2003. Bioremediation of Diesel Oil-Contaminated Soil by Composting with Biowaste. Environmental Pollution, 125, 361-368.

36. Vidali, M. 2001. Bioremediation: An Overview. Pure and Applied Chemistry, 73, 1163-1172.

37. von Wedel R.T., Mosquera S.F., Goldsmith C.D., Hater G.R., Wong A, Fox T.A., Hunt W.T., Paules MS, Quiros J.M., \& Wiegand J.W. 1988. Bacterial Biodegradation of Petroleum Hydrocarbons in Ground Water: In Situ Augumented Bioreclamation with Enrichment Isolates in California. Water Sci Technol; 20, 501-503.

38. Wang, Z., Xu, Y., Zhao, J., Li, F., Gao, D., \& Xing, B. 2011. Remediation of Petroleum Contaminated Soil Through Composting and Rizosphere Degradation. Journal of Hazardous Materials, 190, 677-685.

39. Yudo, S. 2006. Kondisi Pencemaran Logam Berat di Perairan Sungai DKI Jakarta. Jurnal Ilmu Lingkungan, 2(1).

40. Zhang, J., Lin, X., Liu, W., Wang, Y., Zeng, J., \& Chen, H. 2012. Effect of Organic Wastes on The Plant-Microbe Remediation for Removal of Aged PAHs in Soil. Journal of Environmental Sciences, 24(8), 147. 